\title{
Enterohaemorrhagic Escherichia coli: emerging issues on virulence and modes of transmission
}

\author{
Alfredo CAPRIOLI ${ }^{\mathrm{a} *}$, Stefano MORABITO ${ }^{\mathrm{a}}$, Hubert BRUGÈRE $^{\mathrm{b}}$, \\ Eric OSWALD ${ }^{\mathrm{b}}$ \\ ${ }^{a}$ Dipartimento di Sanità Alimentare e Animale, Istituto Superiore di Sanità, \\ Viale Regina Elena 299, 00161 Rome, Italy \\ b UMR1225 INRA “Interactions Hôtes-Agents Pathogènes", École Nationale Vétérinaire de Toulouse, \\ 23 chemin des Capelles, 31076 Toulouse Cedex, France
}

(Received 13 May 2004; accepted 3 August 2004)

\begin{abstract}
Enterohaemorrhagic Escherichia coli (EHEC) constitute a subset of serotypes (E. coli O157 and some other serogroups) of Shiga toxin (Stx)-producing E. coli (STEC) firmly associated with severe human illnesses like bloody diarrhoea and haemolytic uraemic syndrome. Stx production is essential but not sufficient for EHEC virulence. Most strains are capable of colonising the intestinal mucosa of the host with the "attaching and effacing" mechanism, genetically governed by a large pathogenicity island (PAI) defined as the Locus of Enterocyte Effacement. Other virulence factors carried by mobile genetic elements like PAI and plasmids have been recently described, and their role in the pathogenic process has not been fully elucidated. EHEC are zoonotic pathogens. They rarely cause disease in animals, and ruminants are recognised as their main natural reservoir. Cattle are considered to be the most important source of human infections with EHEC O157, and the ecology of the organism in cattle farming has been extensively studied. The organism has also been reported in sheep, goats, water buffalos, and deer. Pigs and poultry are not considered to be a source of EHEC and the sporadic reports may derive from accidental exposure to ruminant dejections. The epidemiology of EHEC infections has remarkably changed during the past ten years and an increasing number of unusual food vehicles have been associated with human infections. New routes of transmission have emerged, like contact with animals during farm visits and a wide variety of environment-related exposures. As for other zoonotic agents, having animals and raw products that are free from EHEC is not possible in practice. However, their occurrence can be minimised by applying high standards of hygiene in all the steps of the food production chain.
\end{abstract}

enterohemorrhagic E. coli / E. coli O157 / Shiga toxins / foodborne zoonoses

\section{Table of contents}

1. Introduction 290

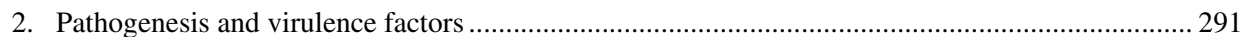

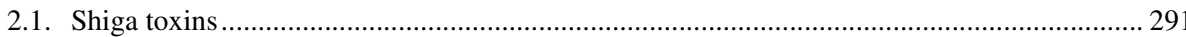

2.2. The Locus for Enterocyte Effacement .............................................................................. 291

2.3. Other mechanisms of intestinal adhesion......................................................................... 292

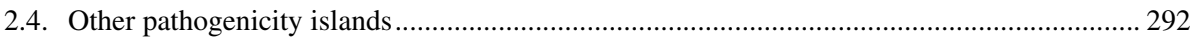

\footnotetext{
* Corresponding author: a.caprio@iss.it
} 


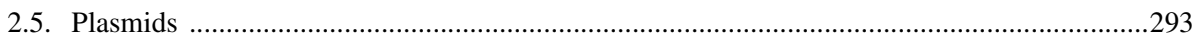

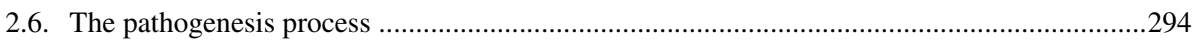

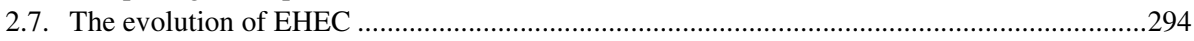

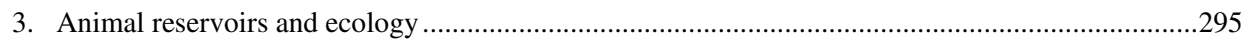

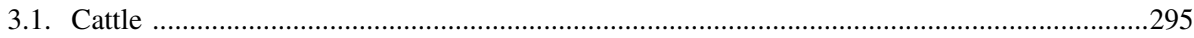

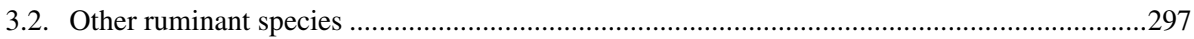

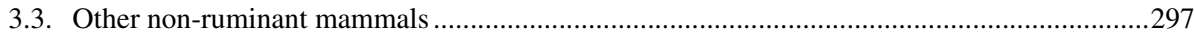

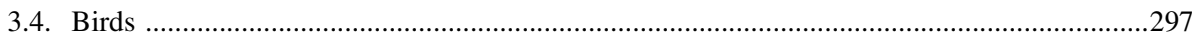

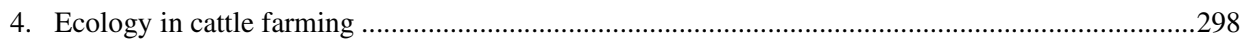

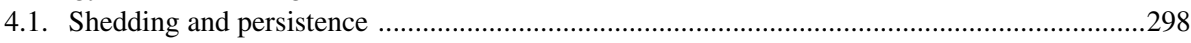

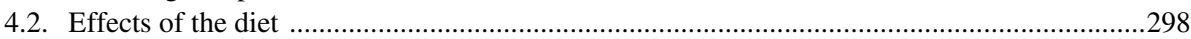

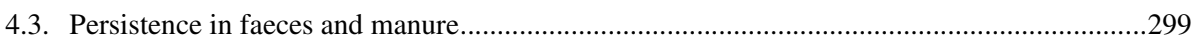

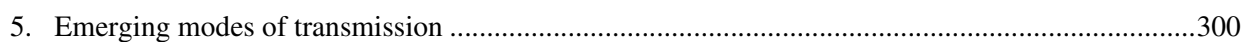

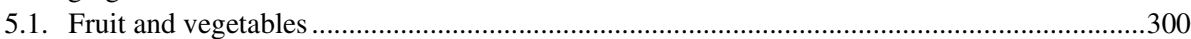

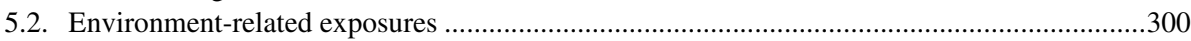

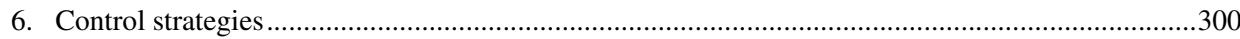

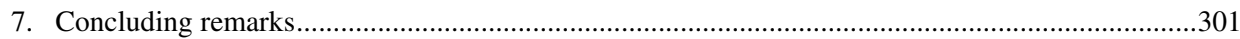

\section{INTRODUCTION}

Escherichia coli is part of the normal micro flora of the gastrointestinal tract of mammals and birds, but certain strains have been associated with gastrointestinal diseases in both humans and animals. These E. coli strains have been categorised into pathogenicity groups, based on their virulence properties [120]. One of these groups is characterised by the production of potent cytotoxins that inhibit protein synthesis within eukaryotic cells. These toxins are either termed verocytotoxins (VT), because of their activity on Vero cells, or Shiga toxins (Stx), because of their similarity with the toxin produced by Shigella dysenteriae [110]. Therefore, these strains are either termed Stx-producing E. coli (STEC) or VT-producing E. coli (VTEC).

STEC infections have been described in a wide range of both domestic and wild animal species, but their natural pathogenic role has been demonstrated only in young calves (diarrhoea or dysentery), weaning pigs (oedema disease), and dogs (cutaneous and renal vasculopathy in greyhounds) [180]. In human beings, conversely, STEC infections are relatively uncommon, but they can cause severe illnesses such as hemorrhagic colitis and haemolytic uraemic syndrome
(HUS), especially among children and the elderly [123].

Enterohaemorrhagic E. coli (EHEC) constitute a subset of serotypes of STEC that has been firmly associated with bloody diarrhoea and HUS in industrialised countries $[61,120]$. The majority of the cases of disease worldwide are caused by strains of serotype O157:H7, but infections sustained by EHEC strains belonging to serogoups other than O157, like O26, O111, O103, and $\mathrm{O} 145$ have been increasingly reported $[120,167]$. These strains are now usually referred to as non-O157 EHEC. This paper will review the recent findings on pathogenesis and virulence factors, trying to seek out what makes a STEC, an EHEC highly pathogenic to humans.

STEC/EHEC represent the only pathogenic group of $E$. coli that has a definite zoonotic origin, with cattle being recognised as the major reservoir for human infections. The role of ruminant and non ruminant species as reservoirs, the ecology of EHEC in the animal niches and some emerging modes of transmission of the infection will also be discussed, together with possible strategies to control the infection all along the food chain. 


\section{PATHOGENESIS AND VIRULENCE FACTORS}

An important objective of the studies conducted in recent years on virulence and pathogenicity has been to define the combination of virulence genes and the mechanisms that make a STEC strain an EHEC fully pathogenic to humans. The production of Stx appears to be essential but not solely responsible for the pathogenic effects. As a matter of fact, EHEC associated with severe human disease are usually capable of colonising the intestinal mucosa with a characteristic "attaching and effacing" mechanism and possess virulence plasmids, while these properties are significantly less common among STEC strains isolated from healthy cattle. An increasing number of additional virulence factors has been described, and they are usually carried by mobile genetic elements like plasmids and pathogenicity islands (PAI), large genetic elements carrying virulence genes and inserted in chromosomal loci encoding tRNA [63].

\subsection{Shiga toxins}

Stx are considered to be the major virulence factor of EHEC and comprise a family of structurally related cytotoxins with similar biological activity. The two main groups consist of Stx 1 , which is nearly identical to the toxin of S. dysenteriae type 1, and Stx2, which shares less than $60 \%$ amino acid sequence with Stx1 [110]. The genetic information for the production of Stx 1 and Stx 2 is located in the genome of lambdoid prophages integrated in the STEC chromosome [110]. Whereas Stx1 shows only little sequence variations [189], several variants of Stx2 with altered antigenic or biological characteristics have been described. Such toxins have been termed Stx2c, Stx2d, Stx2e and Stx2f [110, 147]. Besides these toxins, which have been reported in a relevant number of strains, several reports on other Stx2 variants produced by single strains have been published [147]. Epidemiological studies have revealed that Stx2 is more associated with severe human dis- ease than Stx1 [13]. Among the Stx2 variants, Stx 2 and Stx2c have been frequently found in strains isolated from patients with HUS, while strains producing Stx2d are usually isolated from cases of uncomplicated diarrhoea [53]. Other variants are produced by strains of animal origin and are rarely observed in human isolates: Stx2e is mainly found in STEC causing oedema disease in pigs [102] and Stx2f appears to be closely associated with STEC of avian origin [149].

\subsection{The Locus for Enterocyte Effacement}

Most STEC included in the EHEC group colonise the intestinal mucosa with a mechanism that subverts the epithelial cell function [52] and induces a characteristic histopathologic lesion, defined as "attaching and effacing" (A/E). The A/E lesion is due to marked cytoskeletal changes and is characterised by effacement of microvilli and intimate adherence between the bacteria and the epithelial cell membrane, with accumulation of polymerised actin directly beneath the adherent bacteria [120].

The complex mechanism of A/E adhesion is genetically governed by a large PAI defined as the Locus of Enterocyte Effacement (LEE) [52, 120], and epidemiological studies have shown that LEE-positive strains are highly associated with severe human disease [13]. LEE is constituted of three functionally different modules. The first encodes a type III secretion system (TTSS) that exports effector molecules. The second encodes the secreted proteins EspA, B, and D, which function as part of the type III secretion apparatus. The third encodes the adhesin "intimin" and the "translocated intimin receptor" (Tir), which is translocated into the host cell plasma membrane by the TTSS [36].

Intimin mediates the intimate attachment of EHEC and also of enteropathogenic E. coli (EPEC) to the host cell, and its important role in the pathogenic process has been demonstrated $[34,120]$. The intimincoding genes (eae) present a considerable 
heterogeneity in their 3' end that encodes the $\mathrm{C}$-terminal 280 amino acids involved in binding to the enterocytes and Tir [52, 70], and the corresponding changes in the amino acid sequence also represent antigenic variations. Based on the sequence and antigenic differences in this C-terminal cellbinding domain, several distinct intimin types have been identified and classified with a nomenclature system based on the Greek alphabet. The main types are termed $\alpha, \beta, \varepsilon, \gamma[129]$. Intimin $\alpha$ is generally found in EPEC, while types $\gamma$ and $\varepsilon$ are closely associated with EHEC: intimin $\gamma$ is produced by serogroups $\mathrm{O} 157, \mathrm{O} 111$, and O145, while intimin $\varepsilon$ by serogroups $\mathrm{O} 103$ and $\mathrm{O} 121$. Intimin $\beta$ can be found in both EPEC and EHEC, the most important EHEC serogroup producing intimin $\beta$ being O26. Several other less frequent eae gene variants have been described, and a PCR typing scheme for their identification has been developed [190]. It has been hypothesised that the wide variability in the polypeptide cellbinding domain of intimin could play a role in the tissue tropism of the different intiminproducing E. coli. EPEC, which produce $\beta$ intimins, can colonise almost all regions of the small bowel, while binding of $\gamma$ intiminpositive EHEC strains is restricted to the follicle-associated epithelium of the Peyers patches [51].

In addition to Tir, LEE-positive EHEC use the TTSS to inject several effector proteins directly into the eukaryotic cell, where the normal cellular functions are subverted to the benefit of the bacteria. To date, seven EPEC and EHEC effector molecules have been shown to be injected into the host cell by the TTSS. Five translocated effectors are encoded by LEE: Tir/EspE [35, 88], Map [87], EspF [109], EspG [45] and EspH [169]. Two effectors are encoded outside the LEE by lambdoid prophages: Cif [104] and NleA/EspI [62, 118]. Blast analysis revealed that homologues of NleA/EspI are encoded by an Stx1-converting phage in EHEC of serotype O84:H4 (unpublished results) or by the phage coding for Cif [104]. Other potential type III effectors encoded outside the LEE have also been identified using a proteomic approach [38]. These non-LEE effectors are encoded by lambda-like phages or by putative PAI, such as PAI O\#122, also termed SpLE3, integrated near tRNA pheV in EHEC O157 [71, 134]. The set of translocated effector molecules tends to be unique to each pathogen: it reflects the needs and specific niches of each bacterial species [76] and could also determine the clinical manifestation of disease in the host. The repertoire of LEEencoded effectors does not explain the full spectrum of pathologic phenomena induced by infections with EHEC in the host. The newly identified non-LEE-encoded effectors will open up new areas of investigation to increase our understanding of EHECmediated diseases.

\subsection{Other mechanisms of intestinal adhesion}

LEE-negative STEC are rarely isolated from cases of bloody diarrhoea or HUS and are usually not included among EHEC. A few exceptions have been reported in the literature, in which other mechanisms of adhesion could have allowed the strains to colonise the intestinal mucosa as efficiently as the $\mathrm{A} / \mathrm{E}$, and hence to cause disease. STEC O111:H2 from an outbreak of HUS were shown to display aggregative adhesion to HEp-2 cells instead of the localised adhesion typical of A/E E. coli and to possess the genetic markers of enteroaggregative $E$. coli instead of the LEE [115]. Tissue cultureadherent STEC of serotype O113:H21 have been isolated from patients with HUS [44]. STEC O113 produce an autoagglutinating adhesin, encoded by a genetic locus, termed $s a a$, which could have a role in the colonisation of the host intestinal mucosa [132].

\subsection{Other pathogenicity islands}

Genetic analysis of the complete DNA sequence of EHEC O157:H7 [71, 134] showed that almost $20 \%$ of its chromosome is constituted of foreign DNA not present in 
the chromosome of $E$. coli $\mathrm{K}-12$, which has probably been acquire from other bacterial species through horizontal gene transfer [142]. Similarly to LEE, other regions of this foreign DNA can be considered as putative PAI since they carry virulence-associated genes, show a lower GC content, and are inserted in tRNA loci [63]. Some of these PAI are not restricted to EHEC O157, but have been observed in other EHEC serogroups and in E. coli strains belonging to other diarrhoeagenic groups $[117,160]$. In particular, a PAI termed O\#122 is present in most EHEC and EPEC, but not in other groups of E. coli. In many clones, PAI O\#122 and LEE are physically linked to form a larger mosaic PAI, and that could be the basis of the association with EHEC and EPEC. In EHEC O157, PAI O\#122 is located apart from the LEE, and it has been hypothesised that the two islands can have separated after being acquired as a unique large PAI, following events of chromosomal rearrangement [117]. PAI O\#122 carries efal/lifA, a $10 \mathrm{~kb}$ virulence gene that has been involved with both the repression of host lymphocyte activation response [89] and the adhesion to cultured cells [121]. In vivo, the presence of this gene has been associated with the capability of colonising the intestinal tract of cattle and of inducing diarrhoea in young calves [157]. The PAI O\#122 of EHEC O157 possess only the 5' region of efal/lifA, but even that portion of the gene appears to have a role in its adherence properties [159].

Another PAI first described in pathogenic Yersinia species and termed high-pathogenicity island (HPI) has been reported in EHEC. It encodes the pesticin receptor FyuA and the siderophore yersiniabactin, and has been detected in EHEC O26 strains, but not in EHEC belonging to serogroups O157, $\mathrm{O} 103$ and $\mathrm{O} 111[85]$.

\subsection{Plasmids}

EHEC O157 possess a large virulence plasmid of approximately $90 \mathrm{~Kb}$ termed pO157. The nucleotide sequence of this plasmid showed that it encodes 35 proteins, some of which are presumably involved in the pathogenesis of EHEC infections [21]. The hly operon encodes four ORF necessary for the synthesis and transport of the enterohaemolysin and confers to EHEC the enterohaemolytic phenotype [150]. The hly operon is considered as the best marker of the presence of pO157 and is also present in large plasmids that can be detected in most non-O157 EHEC strains [19]. pO157 also carries a type II secretion system related to the pullulanase secretion pathway of Klebsiella, but its function has yet to be elucidated [151]. Other putative virulence factors harboured by this plasmid comprise a katalase-peroxyidase and a serine protease, encoded by katP and espP genes, respectively [150]. The involvement of these factors in EHEC pathogenesis is unclear, but antibodies to the espP product have been found in convalescent-phase sera from children who suffered from EHEC infection [150]. pO157 is a dynamic structure, which includes different mobile genetic elements such as transposons, prophages and parts of other plasmids assembled together by recombination events [20]. As a consequence, the plasmid-encoded determinants are unevenly distributed among EHEC O157 strains. The hly operon and the type II secretion system are present in almost all the isolates, while $k a t P$ and $e s p P$ can be detected in two thirds of the strains [150]. Another virulence gene, termed tox $B$, has been recently described in pO157 [159] and it appears to be present in all the EHEC O157 isolates (unpublished results). The product of tox $B$ seems to be involved in the colonisation of the host gut by influencing the expression of the LEEencoded type III secreted proteins and by inhibiting the activation of host lymphocytes [159]. These biological activities are similar to those conferred by the efal/ lifAgene carried by PAI O\#122 [89, 117, 121]. Both toxB and efal/lifA are large genes, which show a 50\% mean homology in the aminoacid sequence, although there are no significant homologies at the nucleotide level. It is interesting to note that 
EHEC O157, which possess toxB, carries only a small portion of efal/lifA corresponding to the 5' region of the gene [117, 134]. Conversely, most non-O157 EHEC have the entire efal/lifA [117] but did not present tox $B$ sequences (unpublished results).

Large plasmids resembling pO157 can be found in most non-O157 EHEC strains. These plasmids usually carry the hly operon, while other markers like the type II secretion system, katP and espP can be found in less than $50 \%$ of the isolates [150]. These findings probably reflect the remarkable plasticity of this group of large virulence plasmids.

\subsection{The pathogenesis process}

EHEC are highly infectious to human beings. The infection is usually acquired by ingestion of contaminated food or water or by person-to-person spread through close contact. Outbreaks or incidents of illness are believed to result from a very low infective dose, e.g. $<100$ cells, but people may carry EHEC as part of their transient gut microflora without disease $[61,123,155]$. When these organisms do cause illness, very serious clinical manifestations can occur, including haemorrhagic colitis and HUS. This latter condition usually occurs in children under five years of age and is the major cause of acute renal failure in children $[61,123]$. The pathogen and host factors that contribute to the clinical manifestations of EHEC infection are the subject of considerable ongoing investigations and the pathogenesis process is still not fully understood. Stx production is a prerequisite for EHEC mediated diseases. The toxin is able to pass through the intestinal epithelium to reach its target on endothelial cells lining small blood vessels that supply the gut, kidney and other viscera [162]. In addition to exacerbating the intestinal damage associated with infection, Stx are responsible for life-threatening post-diarrhoeal complications due to their action on glomerular and brain microvascular endothelial cells and the activation of prothrombotic and proinflammatory cascades that lead to the development of HUS and central nervous system complications [131]. While the mechanism of action of Stx and the resultant cytotoxicity are well described [110], the pathogenic mechanism(s) leading to the profound vascular damage seen in HUS is less well understood. Possible contributors to pathogenesis may include bacterial lipopolysaccharides and the proinflammatory cytokines tumour necrosis factor $\alpha$ and interleukin-1 $\beta$ [161].

Besides Stx production, colonisation of the host intestinal mucosa is another key determinant of virulence, and several virulence factors involved in the process have now been characterised, as discussed in the above paragraphs. In conclusion, not all the strains of STEC are able to cause haemorrhagic colitis or HUS, and those that do carry virulence determinants in addition to Stx. However, it is still not clear why only the subset of STEC defined EHEC have narrow host specificity and are human pathogens.

\subsection{The evolution of EHEC}

It is a mistake to think of EHEC as a homogenous pathogroup. EHEC strains fall into at least four divergent clonal groups [42, 178] (http://www.shigatox.net/stec/clonal). One clonal group includes EHEC strains of serotype 0157:H7 and the closely related EPEC of serotype O55:H7. A second clonal group includes EHEC strains of serotype O111:H8 and O26:H11. A third group includes EHEC strains of serotype O103:H2 and $\mathrm{O} 45: \mathrm{H} 2$. A fourth group includes many different $\mathrm{O}$ types, usually associated with the H21 flagellar antigen. The most common serotypes are O113:H21, OX3:H21, and O91:H21. Except for the last clonal group, bacteria from the other clonal groups invariably carry the eae gene, but otherwise they display a diverse array of virulence.

The mechanisms underlying the evolution and emergence of EHEC clones are not well understood but it is now clear that the 
composition of the E. coli genome is highly dynamic. Such fluid gain and loss of genetic material is well illustrated by the comparison of the genomic sequence of EHEC O157 with the non-pathogenic laboratory strain $\mathrm{K}-12$ genome [71, 134]. A 4.1-Mb sequence is highly conserved between the two strains and may represent the fundamental backbone of the E. coli chromosome. In contrast, the remaining 1.4-Mb sequence comprises EHEC O157-specific sequences. Molecular analysis suggests that EHEC acquired the majority of their virulence factors by horizontal transfer of genetic material and the acquisition of the LEE PAI and the Stx genes were two crucial steps in the evolution of EHEC O157 from a commensal ancestor [142]. Genetic analyses suggest that EHEC O157 separated from a common ancestor of $E$. coli $\mathrm{K}-12$ as long as 4.5 million years ago [142]. The stepwise model of Feng et al. [48] makes specific predictions about the history of descent and the order of acquisition of virulence factors. Such a model predicts that EHEC O157:H7 and O157:H- were derived from an EPEC-like O55:H7 ancestor that carried the LEE located at the selC site and acquired the bacteriophages carrying the Stx-encoding genes [148]. As far as the LEE is concerned, however, it is not clear how often this transfer took place and which parts of the locus were involved. Like the large EHEC-haemolysin plasmid, the LEE is clearly a mosaic structure, which arose from multiple recombination events with foreign DNA [12, 117]. Interestingly, LEE can be found in or next to tRNA genes at different locations on the chromosomes of different EPEC and EHEC clonal types [183], suggesting that it may have been acquired on more than one occasion.

Despite the wealth of information available, further comparative studies are needed to decipher definitively the evolution of virulence in EHEC. However, the presence of 24 prophages and prophage-like elements that occupy more than half of the EHEC O157-specific sequences suggest a predominant role of bacteriophages $[71,126]$. These prophages, including the Stx-transducing phages, exhibited extensive structural and positional diversity, implying that variation of bacteriophages is a major factor in generating genomic diversity among the EHEC O157 lineage [127]. In addition, it was recently shown that these prophages do not only code for Stx, but also for effector molecules which are recognized by the type III secretion system encoded by the LEE [38, $62,104,118]$. Phages could be the major contributors in the evolution of EHEC virulence and in the emergence of new EHEC clones.

\section{ANIMAL RESERVOIRS AND ECOLOGY}

STEC can be found in the gut of numerous animal species, but ruminants have been identified as a major reservoir of STEC that are highly virulent to humans, in particular EHEC O157. Knowledge about the routes of transmission and the origin of human infections have regularly improved during the past twenty years, as numerous epidemic events have been investigated. So, it seems evident that STEC may be transmitted from animal reservoirs to humans not only via the ingestion of contaminated foods or drinking water, but also by contact with STEC-positive animals or with their environment.

\subsection{Cattle}

Cattle are considered to be the most important source of human infections with EHEC O157, being asymptomatic excretors of the organism, which is a transient member of their normal gut micro flora. The presence of EHEC O157 in cattle excreta appears to be influenced by the age of the animals. Studies conducted in the United States have shown that EHEC O157 could be isolated from the faeces of less than $1.5 \%$ of calves under two months of age [113] and from 1.8 to $5 \%$ of the calves aged between two and four months [46, 188]. Thereafter, the prevalence of EHEC O157 declines [67], 
suggesting that faecal shedding might be more intense and frequent immediately after weaning. Similar results have been reported in investigations performed in England and Wales [130]. Studies conducted with experimental infections have confirmed that EHEC O157 shedding is longer and more intense in calves than in adult cattle [33] and that it largely increases after weaning [57]. A higher rate of faecal shedding after weaning has also been observed in a Japanese study conducted on the presence of STEC regardless their serotype: stx genes were detected in faecal samples from $39.4 \%$ of calves less than 2 months old, $78.9 \%$ of calves from 2 to 8 months old, and $40.8 \%$ of adult cattle [154].

The prevalence of EHEC O157 in cattle also depends on the season, since increased rates of faecal shedding have been repeatedly reported in warmer months $[15,26,65]$. However, a study conducted on the presence of STEC in grazing beef cattle regardless of their serotype showed a higher prevalence in the winter than in the summer [164].

Studies on the presence of STEC in cattle have been performed worldwide. In North America, STEC have been isolated both from beef cattle [151, 163] and dairy cattle [164]. Hancock and co-workers [64] reported the isolation of EHEC $\mathrm{O} 157$ from $0.28 \%$ of dairy cattle ( $8.3 \%$ of the tested herds) and from $0.71 \%$ of beef cattle ( $16 \%$ of the herds). In Brazil, st $x$ genes were detected in the faeces of $82 \%$ of dairy cattle and $53 \%$ of beef cattle, but EHEC O157 was isolated from only $1.5 \%$ of the samples [24]. In Australia, stx genes were present in $16.7 \%$ of faecal samples from dairy cattle [28] and EHEC O157 and EHEC O26:H11 were isolated from 1.9 and $1.7 \%$ of the samples respectively. In Japan, stx genes were detected in the faeces of $46 \%$ of tested calves, $66 \%$ of heifers and $69 \%$ of cows [90]; EHEC O26, O111 and O157 were isolated in 9 of the 78 herds tested (11.5\%). In Europe, studies on STEC faecal shedding have been performed in many countries. The rate of animals carrying STEC ranged from $2.8 \%$ of the tested animals in the UK [186] to $75 \%$ in Norway [171]. When EHEC O157 was isolated, the rate of positive animals ranged from $0.2 \%$ in France [136] to $16.6 \%$ in Italy [15]. In Spain, STEC have been isolated from both calves and adult cattle, with prevalence rates ranging from 20.3 to $36.7 \%$ [10, 11]. In these studies, up to $83 \%$ of the tested herds were positive and the main STEC serogroups isolated were $\mathrm{O} 8, \mathrm{O} 20, \mathrm{O} 22$, O77, O113, O126 and O162. Most of the isolates were negative for the eae gene. In France, a study performed at the slaughterhouse indicated that $18 \%$ of faecal samples were positive for stx genes, and STEC were isolated from $7.9 \%$ of these samples [145]. In another study, however, a much higher prevalence of stx genes (70\%) was observed, and STEC were isolated from more than $30 \%$ of the samples [136].

STEC belonging to serogroups other than O157 can frequently be isolated from young calves with diarrhoea. STEC strains pathogenic to calves usually possess the LEE, produce Stx1, and belong to a restricted number of serogroups: O5, O26, O111, O118 [182]. EHEC O118 strains, in particular, have frequently been isolated from diarrhoeic calves in Germany, [184] and their zoonotic transmission to humans has been demonstrated [7]. In investigations conducted in Germany [181] and Brazil [100], STEC were isolated more frequently from diarrhoeic calves than from healthy calves. Conversely, other studies have reported higher rates of STEC faecal carriage in healthy than in diarrheic animals [9, 141].

The results of the investigations on the prevalence of STEC and/or EHEC O157 in cattle are clearly influenced by the sampling and detection methods adopted. As a matter of fact, the use of specific immunoconcentration procedures for EHEC O157 $[173,187]$ strongly enhances the sensitivity of the isolation methods. Therefore, the studies based on such procedures reported prevalence rates for EHEC O157 much higher that those reported in investigations aimed at revealing all the STEC, regardless 
of their serotype. It is therefore difficult to determine whether the results reported reflect true differences in colonisation rates or are the consequence of the different methodologies adopted.

\subsection{Other ruminant species}

STEC, including EHEC O157 and other serogroups associated with human infections like O91, O128 and O146, have been frequently isolated from the intestinal content of sheep [72, 140, 171]. EHEC O157 has also been found in both meat [27] and milk [146] and sheep are now considered as an important reservoir for human infection. EHEC O157 has also been isolated from goats [137], and goat milk has been associated with an outbreak [8]. Small ruminant flocks may also have a relevant role in spreading STEC contamination in the environment $[75,125]$.

The water buffalo is another potential source for STEC infections. A recent survey conducted in southern Italy (unpublished results) showed that buffalo dairy herds were frequently colonised by EHEC O157; yet the organism was not found in a study conducted on mozzarella cheese prepared with unpasteurised buffalo milk [30].

STEC can be found in wild ruminants, and the possible role of these animals as reservoirs for domestic ruminants sharing the same environment has been suggested. EHEC O157 has been repeatedly isolated from deer [143] and the consumption of deer venison has been associated with human infections [86, 139]; these episodes also underline the risk of products derived from private slaughtering.

\subsection{Other non ruminant mammals}

STEC have been sporadically isolated from mammals other than ruminants, but in many cases it is not clear whether they represented actual hosts or merely vectors transiently colonised after contact with ruminant dejections [177]. EHEC O157 have been isolated from companion animals living on a farm environment and associated with human infections, like horses [25, 168] and dogs [168]. The presence of STEC, including EHEC O157, has been recently described in both wild and farmed rabbits $[59,95,138]$ and the possible role of the rabbit as a source of human infections deserves further studies.

Pigs are not considered to be a major source of EHEC O157 and other STEC associated with human infections. Prevalence rates of EHEC O157 faecal carriage ranging from 0.2 to $2 \%$ have been reported in pigs slaughtered in European countries [16, 73, 82], Japan [119] and the United States [47]. The low carriage rate observed in these studies could be the result of accidental exposure of pig herds to EHEC O157 through contamination of feedstuff or the environment with ruminant manure in farms that do not comply with good husbandry practices. However, investigations conducted in South America [17, 144] showed a surprisingly high rate of EHEC O157 faecal carriage (8-10\%) in slaughtered pigs. These marked differences in prevalence may be due to differences in pig husbandry and slaughtering practices.

\subsection{Birds}

STEC have also been isolated from birds. The isolation of EHEC O157 [175] and non-O157 STEC [103] from gull droppings has been reported. The gulls were not considered as a true reservoir of STEC but rather as potential vectors for their dissemination since a low carriage was found and since the birds fed on contaminated sites. STEC strains producing a particular variant of Stx2, designated Stx2f [149], have been frequently isolated from feral pigeons [37]. Most of these strains possessed genes encoding for other virulence factors, such as the intimin and the cytolethal distending toxin [116]. It is difficult to establish whether Sxt2f-producing strains may represent a cause of avian disease or even a potential health hazard for humans. Pigeons seem to 
be a natural reservoir for these particular STEC strains, which could be host adapted.

STEC have not been found in live chickens $[6,73]$ even though EHEC O157 strains have been isolated from retail poultry products $[43,95]$ and from the intestinal content of a turkey [73]. Moreover, the organism has been shown to colonise the caecum of chicks for long periods following experimental infection [3].

\section{ECOLOGY IN CATTLE FARMING}

Many studies have been performed to increase the knowledge of the on-farm ecology of EHEC O157, in order to develop strategies for preventing or reducing carriage and shedding of the organism by cattle.

\subsection{Shedding and persistence}

Faecal shedding of EHEC O157 appears to be transient in cattle. It can last approximately one month in a same animal [5], and colonisation can be more prolonged in the winter than in the summer [152]. The load of EHEC O157 in calves' faeces can range from $10^{2}$ to $10^{5} \mathrm{cfu} / \mathrm{gram}$ of faecal matter $[152,188]$. In a recent study conducted on a breeding farm in Japan [179], faecal shedding of EHEC O157 and EHEC O26 persisted up to 10 and three weeks, respectively. The magnitude of faecal shedding was around $10^{4} \mathrm{cfu} / \mathrm{gram}$ for EHEC 0157 and $10^{2} \mathrm{cfu} / \mathrm{gram}$ for EHEC O26. Some strains of STEC can persist many years in a same cattle herd, and that could explain the role of cattle as a reservoir. Moreover, introductions of new STEC strains via feeds and drinking water are always possible [68].

The importance of the farm environment as a potential source or reservoir of EHEC O157 has been extensively addressed. Lejeune et al. [99] found a $13 \%$ prevalence of EHEC 0157 in commercial feedlot cattle throughout the finishing feeding period prior to slaughter, with the predominance and the persistence of four specific clonal types over a period of four months. In the USA, a same well-identified EHECO157 strain persisted in a farm environment for more than two years [152]. The strain was isolated from cattle but also from other animals such as birds or flies, and from feeds and drinking water. Bad husbandry conditions, such as a wet ground with faecal matter and urine accumulation, seem to favour the persistence of EHEC O157 in feedlot cattle [156]. Cleaning methods and housing conditions are also important. In a cattle herd, a higher prevalence of EHEC O157 was observed when the ground was washed with a jet of water, rather than by dry scraping [58]. In a Swedish study, among calves that carried and shed EHEC O157 in their faeces in the spring, only those kept in a cowshed during the summer remained positive four months later, while the organism was not isolated from the calves grazing a pasture during the same period [83]. The persistence of STEC in calves kept in a cowshed might result from continuous contact between the animals and/or with their environment, that allow regular re-infection.

\subsection{Effects of the diet}

There is no clear relationship between feed composition and STEC faecal shedding in cattle. Some authors formulated the hypothesis that a grain-rich diet may induce mechanisms of STEC acid resistance in the rumen that favour STEC survival and faecal shedding $[18,40]$. However, different studies conducted on hay-fed and grain-fed cattle produced conflicting results: sometimes hay-fed cattle shed EHEC O157 longer than the grain-fed animals [74, 114], and sometimes grain-fed animals shed EHEC O157 longer than cattle grazing a pasture [83]. Other studies have reported no differences between the two categories of animals [ 60 , 64]. The effect of diet on the shedding of EHEC O157 was also investigated by the experimental infection of sheep [91]: hayfed sheep shed the bacterium twice as long 
as, and in larger numbers, than sheep fed with a mixture of corn and pelleted alfalfa.

The effect of fasting has also been investigated, and shown to have only a little effect on faecal shedding and rumen proliferation of EHEC O157 in calves [69].

The presence of EHEC O157 in cattle feeds has been recently investigated in the USA: EHEC O157 was detected in 75 of 504 feed samples $(14.9 \%)$ collected from 54 feedlots and no correlation between the presence of EHEC O157 and generic coliform counts in feeds was observed [41]. Faecal contamination of grassed followed by poor silage management may be a factor favouring the persistence of EHEC O157 carriage in ruminants [49]. On the contrary, EHEC O157 did not survive a good silage fermentation process, indicating that properly ensiled and correctly stored grass is unlikely to be a vector for the transmission of this pathogen among cattle [22]. Experimental inoculation of lactic acid-producing bacteria in silage, which decreases $\mathrm{pH}$ more rapidly during ensiling, appears to hasten the elimination of EHEC O157 from the silage [2].

The quality of drinking water is another important issue in the on farm ecology of EHEC O157. The organism can survive and even grow up in the sediments of a drinking trough contaminated with faeces, which may serve as a long-term reservoir and source of infection for cattle [46, 67, 97, 98, 153, 172].

\subsection{Persistence in faeces and manure}

STEC appear to be well adapted to survive in animal faeces, where they can remain viable for periods ranging from several weeks to many months [107]. Experimental contamination of cattle faeces showed a good survival capacity when faeces were maintained between $15^{\circ} \mathrm{C}$ and $18{ }^{\circ} \mathrm{C}$ [54, 105]. The temperature and the water activity of the faeces influenced the duration of EHEC O157 survival, which was the longer (more than 70 days) when faecal samples spiked with the organism were stored at
$5{ }^{\circ} \mathrm{C}$, and had a water activity of 0.98 at the end of the storage [176]. When cattle faeces contaminated with $10^{8} \mathrm{cfu} / \mathrm{gram}$ of EHEC O157 were kept on the surface of grazing land, the count decreased by 4.0-5.0 log $10 \mathrm{cfu} / \mathrm{gram}$ within 50 days, but the organism was still detectable in the surrounding soil for up to 99 days [14].

Persistence of STEC in the soil $[55,56]$ favours the infection of cattle and makes environmental exposure a risk factor for human infection $[32,75,125,158]$. Animal wastes and effluents from farming operations, including manure and slurries, are frequently applied as a fertiliser to land used for crop or silage production and cattle grazing. The presence and persistence of STEC, and in particular of EHEC O157, in these products may therefore be an important factor in the initial infection and re-infection of cattle $[79,92]$. On the contrary, when cattle manure or slurry are applied on farmland in the production of food crops that are to be consumed in the raw or minimally processed state, appropriate handling of these products is necessary to control the spread of potentially present STEC and limit the risks of human infection [66, 77]. Cattle manure composting before its spread onto land may reduce the risk of transmission of STEC through contaminated vegetables [80, 81, 101].

When STEC-containing manure is applied on land, concomitant periods of heavy rainfall can cause the transport of bacteria to both deeper layers of the soil by leaching, and drains and rivers by run-off $[50,55]$. EHEC 0157 has been isolated from surface waters [96, 108], and an increased risk of waterborne infections was recorded immediately after cattle manure spreading [124]. Waterborne episodes of STEC infection have been increasingly reported $[39,107$, $128,166]$ but the causative agent has rarely been isolated from the related water samples [1, 23].

Cattle husbandry is likely the major source of environmental contamination with STEC. However, it should also be considered that 
the presence of STEC may result from throwing out contaminated wastewaters of human origin [94] or spreading contaminated sewage-sludge onto the land [174].

\section{EMERGING MODES OF TRANSMISSION}

During the 1980s, most of the outbreaks of EHEC O157 infection were food borne and the food vehicles implicated were mostly inadequately cooked hamburgers or other beef products, and unpasteurised milk [61]. In the past ten years, remarkable changes in the epidemiology of human infections have occurred. In addition to foods of bovine origin, several outbreaks have been associated with low $\mathrm{pH}$ products like fermented salami, mayonnaise and yogurt [111]. This has highlighted the tolerance of E. coli $\mathrm{O} 157$ to acidic $\mathrm{pH}$ and its ability to survive the processes of fermentation and drying. In addition, waterborne outbreaks and outbreaks associated with other types of environmentrelated exposures have been increasingly reported [107, 166]. The dispersion of untreated manure in the environment can cause the contamination of different items, which can then act as secondary vehicles of human infections $[29,107]$.

\subsection{Fruit and vegetables}

An increasing spectrum of fruits and vegetables fertilised with ruminant manure or contaminated during harvesting or processing has been involved in outbreaks [107, 166]. Contaminated sprouts have caused episodes of salmonellosis and represent an emerging source of EHEC O157 [112]. Viable organisms have been observed in the inner tissues of sprouts grown from experimentally contaminated seeds [78] and this is a matter of particular concern, since disinfection of the sprout surface could not insure the safety of this ready-to-eat food. Other fresh produce like lettuce, tomatoes, coleslaw, and others $[107,166]$ are established or potential vehicles of STEC infec- tion. Unpasteurised fruit juices, increasingly popular among consumers, represent another safety concern, if the acidic tolerance and the low infectious dose of EHEC O157 are considered. Apple juice, in particular, has been frequently involved in outbreaks $[107$, 166].

\subsection{Environment-related exposures}

An increasing number of outbreaks of EHEC O157 infection have occurred among persons involved in outdoor activities, usually in summer months [166]. Swimming in contaminated waters appears to be an important issue [106], as well as the contamination of drinking water supplies in rural settings, such as springs or wells. Water contamination frequently occurs by animal faeces washed out from the nearby environment $[39,128]$. Outbreaks have also occurred among persons attending open-air events, such as fairs, music festivals, parties, and visits to farms or petting zoos [166]. The sources of infection implicated include well water, exposure to mud contaminated with cattle faeces, and direct contact with animals on display. Visiting a farm is now considered an important risk factor for acquiring severe EHEC infections [122, 133]. Conversely, EHEC O157 has been frequently isolated from farm workers in the absence of disease suggesting that farm residents may develop immunity, possibly by exposure to the more common and less virulent STEC non-O157 [4, 155, 185].

\section{CONTROL STRATEGIES}

As for other zoonotic agents, having animals and raw products that are free from STEC is not possible in practice. However, their occurrence can be minimised by applying high standards of hygiene in all the steps of the food production chain.

At the farm level, classical eradication strategies based on the elimination of positive animals are not feasible, due to the high 
prevalence of colonisation, its transient nature, and the technical difficulties in detecting low levels of the organism in animal faeces. Many approaches have been attempted to reduce the intestinal colonisation in cattle. These include interventions on the diet of the animals, the administration of probiotics as competitive micro flora $[19,165]$ and the use of bacteriophages active on EHEC O157 [93].

These approaches have produced inconclusive and sometimes conflicting results. Moreover the feed regimens and the treatments adopted in experimental trials are often difficult to apply to farming practices. Recently, experimental vaccines aiming at reducing the shedding of EHEC O157 in cattle were developed. Subcutaneous administrations of type III secreted proteins, (mainly EspA, EspB EspD and Tir) are able to decrease shedding of EHEC O157 by cattle [135]. Transgenic tobacco plant cells that express the host cell-binding domain of EHEC O157 intimin have also been tested successfully in a mouse model [84]. Although transgenic plants are not likely to be used for cattle vaccination, at least in Europe, this latter result suggests that an intimin-based vaccination strategy could be successful. However, as for other infectious diseases, good hygiene and management practices remain at the present the best way to reduce the spread and persistence of EHEC O157 on the farm. As discussed in the above paragraphs, these may include cleaning the water troughs where EHEC O157 can survive and even grow up $[67,97,98,152,153$, 172], reducing faecal contamination and humidification of feed, and a correct preparation of silage. Other factors that could favour colonisation and shedding of EHEC O157 like sudden modifications in the diet and the stress derived from movement or overcrowding should be reduced.

Since environmental contamination may have an important role in the transmission of the infection to humans, the handling of the animal dejections represents an important issue. STEC can survive in bovine fae- ces for a considerable time [107], therefore manure and slurries should be properly composted to ensure sterilisation or at least the reduction of the microbial load $[80,81,101]$.

As far as the transmission through the direct contact with animals is concerned, both farmers and people visiting farms should apply hygiene practices. In particular, farms receiving school visits must ensure that adults always control children, facilities for hand washing are easily available, and areas for food consumption are clearly separated from those where the animals are kept.

At the abattoir level, no specific procedures for STEC elimination can be applied. However, good hygiene and manufacturing practices as well as implementation of HACCP will contribute to reducing faecal contamination of carcasses.

The general principles of food hygiene will also be effective in preventing EHEC infections at the processing and retail levels of the food chain. In particular, cross contamination between raw and ready to eat products must be avoided, bearing in mind that several large outbreaks $[31,170]$ have originated from gross failures in this basic point. Microbiological testing of meat lots consumed by persons who have become ill suggests that the infectious dose for EHEC O157 might be very low $[61,123]$. This represents a strong argument for enforcing zero tolerance for this organism in processed food and for markedly decreasing contamination of raw ground beef.

\section{CONCLUDING REMARKS}

Despite the great efforts, the studies on the virulence and the evolution of EHEC have only unravelled part of these complicated phenomena. Understanding the factors that govern the development of severe disease in human beings, and the colonisation of the animal hosts would provide the insights for more effective intervention on both these aspects. Moreover, defining the combination of virulence genes and the 
mechanisms that make a STEC strain fully pathogenic will be pivotal to improve the efficacy of both the diagnostics of human infections and the surveillance of animal reservoirs and the assessment of public health risks.

The epidemiology of EHEC infections has remarkably changed during the past ten years. The organisms have been reported in a large variety of domestic and wild animal species, and an increasing number of unusual food vehicles have been associated with human infections. New routes of transmission have emerged, like contact with animals during farm visits and a wide variety of environment-related exposures. In particular, the isolation of EHEC from a growing spectrum of animal species, which can either act as true natural hosts or merely as occasional vectors, suggests that investigations on episodes of human disease with a potential link to a rural environment should be conducted with an open mind and that previously non described animal reservoirs, or food, or environmental vehicles should be considered and tested.

\section{AKNOWLEDGEMENTS}

This work was supported by grant QLK22000-00600 (Attaching/Effacing Escherichia coli: pathogenesis, host response, and epidemiology) from the European Union, and by grant $3 \mathrm{AAF}$ (Control of Foodborne Zoonoses) from the Italian Ministry of Health.

\section{REFERENCES}

[1] Akashi S., Joh K., Tsuji A., Ito H., Hoshi H., Hayakawa T., Ihara J., Abe T., Hatori M., Mori T., A severe outbreak of haemorrhagic colitis and haemolytic uraemic syndrome associated with Escherichia coli O157:H7 in Japan, Eur. J. Pediatr.153 (1994) 650-655.

[2] Bach S.J., McAllister T.A., Baah J., Yanke L.J., Veira D.M., Gannon V.P., Holley R.A., Persistence of Escherichia coli $\mathrm{O} 157: \mathrm{H} 7$ in barley silage: effect of a bacterial inoculant, J. Appl. Microbiol. 93 (2002) 288-294.
[3] Beery J.T., Doyle M.P., Schoeni J.L., Colonisation of chicken cecae by Escherichia coli associated with hemorrhagic colitis, Appl. Environ. Microbiol. 49 (1985) 310-315.

[4] Belongia E.A., Chyou P.H., Greenlee R.T., Perez-Perez G., Bibb W.F., DeVries E.O., Diarrhoea incidence and farm-related risk factors for Escherichia coli O157:H7 and Campylobacter jejuni antibodies among rural children, J. Infect. Dis. 187 (2003) 1460-1468.

[5] Besser T.E., Hancock D.D., Pritchett L.C., McRae E.M., Rice D.H., Tarr P.I., Duration of detection of faecal excretion of Escherichia coli $\mathrm{O} 157: \mathrm{H} 7$ in cattle, J. Infect. Dis. 175 (1997) 726-729.

[6] Beutin L., Geier D., Steinrück H., Zimmermann S., Scheutz F., Prevalence and some properties of verotoxin (Shiga-like toxin)-producing Escherichia coli in seven different species of healthy domestic animals, J. Clin. Microbiol. 31 (1993) 2483-2488.

[7] Beutin L., Bulte M., Weber A., Zimmermann S., Gleier K., Investigation of human infections with verocytotoxin-producing strains of Escherichia coli (VTEC) belonging to serogroup O118 with evidence for zoonotic transmission, Epidemiol. Infect. 125 (2000) 47-54.

[8] Bielaszewska M., Janda J., Blahova K., Minarikova H., Jikova E., Karmali M.A., Laubova J., Sikulova J., Preston M.A., Khakhria R., Karch H., Klazarova H., Nyc O., Human Escherichia coli O157:H7 infection associated with the consumption of unpasteurized goat's milk, Epidemiol. Infect. 119 (1997) 299-305.

[9] Blanco M., Blanco J., Blanco J.E., Ramos J., Enterotoxigenic, verotoxigenic, and necrotoxigenic Escherichia coli isolated from cattle in Spain, Am. J. Vet. Res. 54 (1993) 14461451 .

[10] Blanco M., Blanco J.E., Blanco J., Gonzalez E.A., Mora A., Prado C., Fernandez L., Rio M., Ramos J., Alonso M.P., Prevalence and characteristics of Escherichia coli serotype O157:H7 and other verotoxin-producing E. coli in healthy cattle, Epidemiol. Infect. 117 (1996) 251-257.

[11] Blanco M., Blanco J., Blanco J.E., Mora A., Prado C., Alonso M.P., Mourino M., Madrid C., Balsalobre C., Juarez A., Distribution and characterization of faecal verotoxin-producing Escherichia coli (VTEC) isolated from healthy cattle, Vet. Microbiol. 54 (1997) 309_ 319.

[12] Boerlin P., Chen S., Colbourne J.K., Johnson R., De Grandis S., Gyles C., Evolution of enterohemorrhagic Escherichia coli hemolysin plasmids and the locus for enterocyte 
effacement in shiga toxin-producing $E$. coli, Infect. Immun. 66 (1998) 2553-2561.

[13] Boerlin P., McEwen S.A., Boerlin-Petzold F., Wilson J.B., Johnson R.P., Gyles C.L., Associations between virulence factors of Shiga toxin-producing Escherichia coli and disease in humans, J. Clin. Microbiol. 37 (1999) $497-$ 503.

[14] Bolton D.J., Byrne C.M., Sheridan J.J., McDowell D.A., Blair I.S., The survival characteristics of a non-toxigenic strain of Escherichia coli $\mathrm{O} 157: \mathrm{H7}$, J. Appl. Microbiol. 86 (1999) 407-411.

[15] Bonardi S., Maggi E., Bottarelli A., Pacciarini M.L., Ansuini A., Vellini G., Morabito S., Caprioli A., Isolation of verocytotoxin-producing Escherichia coli $\mathrm{O} 157: \mathrm{H} 7$ from cattle at slaughter in Italy, Vet. Microbiol. 67 (1999) 203-211.

[16] Bonardi S., Brindani F., Pizzin G., Lucidi L., D'Incau M., Liebana E., Morabito S., Detection of Salmonella spp., Yersinia enterocolitica and verocytotoxin-producing Escherichia coli $\mathrm{O} 157$ in pigs at slaughter in Italy, Int. J. Food Microbiol. 85 (2003) 101-110.

[17] Borie C., Montreal Z., Guerrero P., Sanchez M.L., Martinez J., Arellano C., Prado V., Prevalencia y caracterización de Escherichia coli enterohemorrhagica aisladas de bovinos y cerdos sanos faenados en Santiago, Chile, Archivos de Medicina Veterinaria XXIX (1997) 205-212.

[18] Boukhors K., Pradel N., Girardeau J.P., Livrelli V., Ou Said A.M., Contrepois M., Martin C., Effect of diet on Shiga toxin-producing Escherichia coli (STEC) growth and survival in rumen and abomasum fluids, Vet. Res. 33 (2002) 405-412.

[19] Brashears M.M., Galyean M.L., Loneragan G.H., Mann J.E., Killinger-Mann K., Prevalence of Escherichia coli $\mathrm{O} 157: \mathrm{H} 7$ and performance by beef feedlot cattle given Lactobacillus direct-fed microbials, J. Food Prot. 66 (2003) 748-754

[20] Brunder W., Schmidt H., Frosch M., Karch H., The large plasmids of Shiga-toxin-producing Escherichia coli (STEC) are highly variable genetic elements, Microbiology 145 (1999) 1005-1014.

[21] Burland V., Shao Y., Perna N.T., Plunkett G., Sofia H.J., Blattner F.R., The complete DNA sequence and analysis of the large virulence plasmid of Escherichia coli O157:H7, Nucleic Acids Res. 26 (1998) 4196-4204.

[22] Byrne C.M., O'Kiely P., Bolton D.J., Sheridan J.J., McDowell D.A., Blair L.S., Fate of Escherichia coli $\mathrm{O} 157: \mathrm{H} 7$ during silage fer- mentation, J. Food Prot. 65 (2002) 1854 1860 .

[23] Centers for Disease Control, Outbreak of Escherichia coli O157:H7 and Campylobacter among attendees of the Washington County Fair-New York, 1999, Morb. Mortal. Wkly. Rep. 48 (1999) 803-805.

[24] Cerqueira A.M., Guth B.E., Joaquim R.M., Andrade J.R., High occurrence of Shiga toxinproducing Escherichia coli (STEC) in healthy cattle in Rio de Janeiro State, Brazil, Vet. Microbiol. 70 (1999) 111-121.

[25] Chalmers R.M., Salmon R.L., Willshaw G.A., Cheasty T., Looker N., Davies I., Wray C., Vero-cytotoxin-producing Escherichia coli O157 in a farmer handling horses, Lancet 349 (1997) 1816.

[26] Chapman P.A., Siddons C.A., Cerdan Malo A.T., Harkin M.A., A 1-year study of Escherichia coli $\mathrm{O} 157$ in cattle, sheep, pigs and poultry, Epidemiol. Infect. 119 (1997) 245250.

[27] Chapman P.A., Siddons C.A., Cerdan Malo A.T., Harkin M.A., A one year study of Escherichia coli $\mathrm{O} 157$ in raw beef and lamb products, Epidemiol. Infect. 124 (2000) 207-213.

[28] Cobbold R., Desmarchelier P., Characterisation and clonal relationships of Shiga-toxigenic Escherichia coli (STEC) isolated from Australian dairy cattle, Vet. Microbiol. 79 (2001) 323-335.

[29] Coia J.E., Sharp J.C., Campbell D.M. Curnow J., Ramsay C.N., Environmental risk factors for sporadic Escherichia coli O157 infection in Scotland: results of a descriptive epidemiology study, J. Infect. 36 (1998) 317 321.

[30] Conedera G., Dalvit P., Martini M., Galiero G., Gramaglia M., Goffredo E., Loffredo G., Morabito S., Ottaviani D., Paterlini F., Pezzotti G., Pisanu M., Semprini P., Caprioli A., Verocytotoxin-producing Escherichia coli $\mathrm{O} 157$ in minced beef and dairy products in Italy, Int. J. Food Microbiol. 96 (2004) 67-73.

[31] Cowden J.M., Ahmed S., Donaghy M., Riley A., Epidemiological investigation of the central Scotland outbreak of Escherichia coli O157 infection, November to December 1996, Epidemiol. Infect. 126 (2001) 335-341.

[32] Crampin M., Willshaw G., Hancock R., Djuretic T., Elstob C., Rouse A., Cheasty T., Stuart J., Outbreak of Escherichia coli $\mathrm{O} 157$ infection associated with a music festival, Eur. J. Clin. Microbiol. Infect. Dis. 18 (1999) 286288. 
[33] Cray W.C. Jr, Moon H.W., Experimental infection of calves and adult cattle with Escherichia coli O157:H7, Appl. Environ. Microbiol. 61 (1995) 1586-1590.

[34] Dean-Nystrom E.A., Bosworth B.T., Moon H.W., O'Brien A.D., Escherichia coli O157:H7 requires intimin for enteropathogenicity in calves, Infect. Immun. 66 (1998) 4560-4563.

[35] Deibel C., Kramer S., Chakraborty T., Ebel F., EspE, a novel secreted protein of attaching and effacing bacteria, is directly translocated into infected host cells, where it appears as a tyrosine-phosphorylated $90 \mathrm{kDa}$ protein, Mol. Microbiol. 28 (1998) 463-474.

[36] Delahay R.M., Frankel G., Knutton S., Intimate interactions of enteropathogenic Escherichia coli at the host cell surface, Curr. Opin. Infect. Dis. 14 (2001) 559-565.

[37] Dell'Omo G., Morabito S., Quondam R., Agrimi U., Ciuchini F., Macrì A., Caprioli A., Feral pigeons as a source of verocytotoxin-producing Escherichia coli, Vet. Rec. 142 (1998) 309-310.

[38] Deng W., Puente J.L., Gruenheid S., Li Y., Vallance B.A., Vazquez A., Barba J., Ibarra J.A., O'Donnell P., Metalnikov P., Ashman K., Lee S., Goode D., Pawson T., Finlay B.B., Dissecting virulence: systematic and functional analyses of a pathogenicity island, Proc. Natl. Acad. Sci. USA 101 (2004) 3597-3602.

[39] Dev V.J., Main M., Gould I., Waterborne outbreak of Escherichia coli O157, Lancet 337 (1991) 1412.

[40] Diez-Gonzalez F., Callaway T.R., Kizoulis M.G., Russell J.B., Grain feeding and the dissemination of acid-resistant Escherichia coli from cattle, Science 281 (1998) 1666-1668.

[41] Dodd C.C., Sanderson M.W., Sargeant J.M., Nagaraja T.G., Oberst R.D., Smith R.A., Griffin D.D., Prevalence of Escherichia coli O157 in cattle feeds in Midwestern feedlots, Appl. Environ. Microbiol. 69 (2003) 5243-5247.

[42] Donnenberg M.S., Whittam T.S., Pathogenesis and evolution of virulence in enteropathogenic and enterohemorrhagic Escherichia coli, J. Clin. Invest. 107 (2001) 539-548.

[43] Doyle M.P., Schoeni J.L., Isolation of Escherichia coli O157:H7 from retail fresh meats and poultry, Appl. Environ. Microbiol. 53 (1987) 2394-2396.

[44] Dytoc M.T., Ismaili A., Philpott D.J., Soni R., Brunton J.L., Sherman P.M., Distinct binding properties of eaeA-negative Verocytotoxinproducing Escherichia coli of serotype O113:H21, Infect. Immun. 62 (1994) 34943505 .
[45] Elliott S.J., Krejany E.O., Mellies J.L., RobinsBrowne R.M., Sasakawa C., Kaper J.B., EspG, a novel type III system-secreted protein from enteropathogenic Escherichia coli with similarities to VirA of Shigella flexneri, Infect. Immun. 69 (2001) 4027-4033.

[46] Faith N.G., Shere J.A., Brosch R., Arnold K.W., Ansay S.E., Lee M.S., Luchansky J.B., Kaspar C.W., Prevalence and clonal nature of Escherichia coli $\mathrm{O} 157: \mathrm{H} 7$ on dairy farms on Wisconsin, Appl. Environ. Microbiol. 62 (1996) 1519-1525.

[47] Feder I., Wallace F.M., Gray J.T., Fratamico P., Fedorka-Cray P.J., Pearce R.A., Call J.E., Perrine R., Luchansky J.B., Isolation of Escherichia coli $\mathrm{O} 157$ from intact colon faecal samples of swine, Emerg. Infect. Dis. 9 (2003) 380-383.

[48] Feng P., Lampel K.A., Karch H., Whittam T.S., Genotypic and phenotypic changes in the emergence of Escherichia coli O157:H7, J. Infect. Dis. 177 (1998) 1750-1753.

[49] Fenlon D.R., Wilson J., Growth of Escherichia coli $\mathrm{O} 157$ in poorly fermented laboratory silage: a possible environmental dimension in the epidemiology of E. coli O157, Lett. Appl. Microbiol. 30 (2000) 118-121.

[50] Fenlon D.R., Ogden I.D., Vinten A., Svoboda I., The fate of Escherichia coli and E. coli O157 in cattle slurry after application to land, Symp. Ser. Soc. Appl. Microbiol. 29 (2000) 149S-156S.

[51] Fitzhenry R.J., Pickard D.J., Hartland E.L., Reece S., Dougan G., Phillips A.D., Frankel G., Intimin type influences the site of human intestinal mucosal colonisation by enterohaemorrhagic Escherichia coli O157:H7, Gut 50 (2002) 180-185.

[52] Frankel G., Phillips A.D., Rosenshine I., Dougan G., Kaper J.B., Knutton S., Enteropathogenic and enterohaemorrhagic Escherichia coli: more subversive elements, Mol. Microbiol. 30 (1998) 911-921.

[53] Friedrich A.W., Bielaszewska M., Zhang W.L., Pulz M., Kuczius T., Ammon A., Karch H., Escherichia coli harboring Shiga toxin 2 gene variants: frequency and association with clinical symptoms, J. Infect. Dis. 185 (2002) 74 84.

[54] Fukushima H., Hoshina K., Gomyoda M., Long-term survival of shiga toxin-producing Escherichia coli O26, O111, and O157 in bovine faeces, Appl. Environ. Microbiol. 65 (1999) 5177-5181.

[55] Gagliardi J.V., Karns J.S., Leaching of Escherichia coli $\mathrm{O} 157: \mathrm{H7}$ in diverse soils under various agricultural management practices, Appl. Environ. Microbiol. 66 (2000) 877-883. 
[56] Gagliardi J.V., Karns J.S., Persistence of Escherichia coli O157:H7 in soil and on plant roots, Environ. Microbiol. 4 (2002) 89-96.

[57] Garber L.P., Wells S.J., Hancock D.D., Doyle M.P., Tuttle J., Shere J.A., Zhao T., Risk factors for fecal shedding of Escherichia coli O157:H7 in dairy calves, J. Am. Vet. Med. Assoc. 207 (1995) 46-49.

[58] Garber L.P., Wells S.J., Schroeder-Tucker L., Ferris K., Factors associated with fecal shedding of verotoxin-producing Escherichia coli O157 on dairy farms, J. Food Prot. 62 (1999) 307-312.

[59] Garcia A., Fox J.G., The rabbit as a new reservoir host of enterohemorrhagic Escherichia coli, Emerg. Infect. Dis. 9 (2003) 1592-1597.

[60] Grauke L.J., Wynia S.A., Sheng H.Q., Yoon J.W., Williams C.J., Hunt C.W., Hovde C.J., Acid resistance of Escherichia coli O157:H7 from the gastrointestinal tract of cattle fed hay or grain, Vet. Microbiol. 95 (2003) 211-225.

[61] Griffin P.M., Tauxe A.V., The epidemiology of infections caused by Escherichia coli O157:H7, other enterohemorrhagic E. coli and the associated hemolytic uremic syndrome, Epidemiol. Rev. 13 (1991) 60-98.

[62] Gruenheid S., Sekirov I., Thomas N.A., Deng W., O'Donnell P., Goode D., Li Y., Frey E.A., Brown N.F., Metalnikov P., Pawson T., Ashman K., Finlay B.B., Identification and characterization of NleA, a non-LEE-encoded type III translocated virulence factor of enterohaemorrhagic Escherichia coli O157:H7 Mol. Microbiol. 51 (2004) 1233-1249.

[63] Hacker J., Blum-Oehler G., Muhldorfer I., Tschape H., Pathogenicity islands of virulent bacteria: structure, function and impact on microbial evolution, Mol. Microbiol. 23 (1997) 1089-1097.

[64] Hancock D.D., Besser T.E., Kinsel M.L., Tarr P.I., Rice D.H., Paros M.G., The prevalence of Escherichia coli O157.H7 in dairy and beef cattle in Washington State, Epidemiol. Infect. 113 (1994) 199-207.

[65] Hancock D.D., Besser T.E., Rice D.H., Herriot D.E., Tarr P.I., A longitudinal study of Escherichia coli $\mathrm{O} 157$ in fourteen cattle herds, Epidemiol. Infect. 118 (1997) 193-195.

[66] Hancock D.D., Rice D.H., Herriot D.E., Besser T.E., Ebel E.D., Carpenter L.V., Effects of farm manure-handling practices on Escherichia coli $\mathrm{O} 157$ prevalence in cattle, $\mathrm{J}$. Food Prot. 60 (1997) 363-366.

[67] Hancock D.D., Besser T.E., Rice D.H., Ebel E.D., Herriot D.E., Carpenter L.V., Multiple sources of Escherichia coli O157 in feedlots and dairy farms in the northwestern USA, Prev. Med. Vet. 35 (1998) 11-19.

[68] Hancock D., Besser T., Lejeune J., Davis M., Rice D., Control of VTEC in the animal reservoir, Int. J. Food Microbiol. 66 (2001) 7178.

[69] Harmon B.G., Brown C.A., Tkalcic S., Mueller P.O., Parks A., Jain A.V., Zhao T., Doyle M.P., Faecal shedding and rumen growth of Escherichia coli $\mathrm{O} 157: \mathrm{H} 7$ in fasted calves, J. Food Prot. 62 (1999) 574-579.

[70] Hartland E.L., Batchelor M., Delahay R.M., Hale C., Matthews S., Dougan G., Knutton S., Connerton I., Frankel G., Binding of intimin from enteropathogenic Escherichia coli to Tir and to host cells, Mol. Microbiol. 32 (1999) 151-158.

[71] Hayashi T., Makino K., Ohnishi M. Kurokawa K., Ishii K., Yokoyama K., Han C.G., Ohtsubo E., Nakayama K., Murata T., Tanaka M., Tobe T., Iida T., Takami H., Honda T., Sasakawa C., Ogasawara N., Yasunaga T., Kuhara S., Shiba T., Hattori M., Shinagawa H., Complete genome sequence of enterohemorrhagic Escherichia coli $\mathrm{O} 157: \mathrm{H7}$ and genomic comparison with a laboratory strain K-12, DNA Res. 8 (2001) 11-22.

[72] Heuvelink A.E., Van den Biggelaar F.L., De Boer E., Herbes R.G., Melchers W.J., Huis in 't Veld J.H., Monnens L.A., Isolation and characterization of verocytotoxin-producing Escherichia coli $\mathrm{O} 157$ strains from Dutch cattle and sheep, J. Clin. Microbiol. 36 (1998) 878-882.

[73] Heuvelink A.E., Zwartkruis-Nahuis J.T., Van Den Biggelaar F.L., van Leeuwen W.J., De Boer E., Isolation and characterization of verocytotoxin-producing Escherichia coli O157 from slaughter pigs and poultry, Int. J. Food Microbiol. 52 (1999) 67-75.

[74] Hovde C.J., Austin P.R., Cloud K.A., Williams C.J., Hunt C.W., Effect of cattle diet on Escherichia coli $\mathrm{O} 157: \mathrm{H} 7$ acid resistance, Appl. Environ. Microbiol. (1999) 3233-3235.

[75] Howie H., Mukerjee A., Cowden J., Leith J., Reid T., Investigation of an outbreak of Escherichia coli 0157 infection caused by environmental exposure at a scout camp, Epidemiol. Infect. 131 (2003) 1063-1069.

[76] Hueck C.J., Type III protein secretion systems in bacterial pathogens of animals and plants, Microbiol. Mol. Biol. Rev. 62 (1998) 379433.

[77] Islam M., Morgan J., Doyle M.P., Jiang X., Fate of Escherichia coli O157:H7 in manure compost-amended soil and on carrots and 
onions grown in an environmentally controlled growth chamber, J. Food Prot. 67(2004) 574-578.

[78] Itoh Y., Sugita-Konishi Y., Kasuga F., Iwaki M., Hara-Kudo Y., Saito N., Noguchi Y., Konuma H., Kumagai S., Enterohemorrhagic Escherichia coli O157:H7 present in radish sprouts, Appl. Environ. Microbiol. 64 (1998) 1532-1535.

[79] Jiang X., Morgan J., Doyle M.P., Fate of Escherichia coli $\mathrm{O} 157: \mathrm{H7}$ in manure-amended soil, Appl. Environ. Microbiol. 68 (2002) 2605-2609.

[80] Jiang X., Morgan J., Doyle M.P., Fate of Escherichia coli $\mathrm{O} 157: \mathrm{H} 7$ during composting of bovine manure in a laboratory-scale bioreactor, J. Food Prot. 66 (2003) 25-30.

[81] Jiang X., Morgan J., Doyle M.P., Thermal inactivation of Escherichia coli $\mathrm{O} 157: \mathrm{H} 7$ in cow manure compost, J. Food Prot. 66 (2003) 1771-1777.

[82] Johnsen G., Wasteson Y., Heir E., Berget O.I., Herikstad H., Escherichia coli $\mathrm{O} 157: \mathrm{H} 7$ in faeces from cattle, sheep and pigs in the southwest part of Norway during 1998 and 1999, Int. J. Food Microbiol. 65 (2001) 193-200.

[83] Jonsson M.E., Aspan A., Eriksson E., Vagsholm I., Persistence of verocytotoxinproducing Escherichia coli O157:H7 in calves kept on pasture and in calves kept indoors during the summer months in a Swedish dairy herd, Int. J. Food Microbiol. 66 (2001) 55-61.

[84] Judge N.A., Mason H.S., O'Brien A.D., Plant cell-based intimin vaccine given orally to mice primed with intimin reduces time of Escherichia coli $\mathrm{O} 157: \mathrm{H} 7$ shedding in feces, Infect. Immun. 72 (2004) 168-175.

[85] Karch H., Schubert S., Zhang D., Zhang W., Schmidt H., Olschlager T., Hacker J., A genomic island, termed high-pathogenicity island, is present in certain non-O157 Shiga toxin-producing Escherichia coli clonal lineages, Infect. Immun. 67 (1999) 5994-6001.

[86] Keene W.E., Sazie E., Kok J., Rice D.H., Hancock D.D., Balan V.K., Zhao T., Doyle M.P., An outbreak of Escherichia coli O157:H7 infections traced to jerky made from deer meat, JAMA 277 (1997) 1229-1231.

[87] Kenny B., Jepson M., Targeting of an enteropathogenic Escherichia coli (EPEC) effector protein to host mitochondria, Cell. Microbiol. 2 (2000) 579-590.

[88] Kenny B., DeVinney R., Stein M., Reinscheid D.J., Frey E.A., Finlay B.B., Enteropathogenic E. coli (EPEC) transfers its receptor for intimate adherence into mammalian cells, Cell 91 (1997) 511-520.

[89] Klapproth J.M., Scaletsky I.C., McNamara B.P., Lai L.C., Malstrom C., James S.P., Donnenberg M.S., A large toxin from pathogenic Escherichia coli strains that inhibits lymphocyte activation, Infect. Immun. 68 (2000) 2148-2155.

[90] Kobayashi H., Shimada J., Nakazawa M., Morozumi T., Pohjanvirta T., Pelkonen S., Yamamoto K., Prevalence and characteristics of shiga toxin-producing Escherichia coli from healthy cattle in Japan, Appl. Environ. Microbiol. 67 (2001) 484-489.

[91] Kudva I.T., Hunt C.W., Williams C.J., Nance U.M., Hovde C.J., Evaluation of dietary influences on Escherichia coli O157:H7 shedding by sheep, Appl. Environ. Microbiol. 63 (1997) 3878-3886.

[92] Kudva I.T., Blanch K., Hovde C.J., Analysis of Escherichia coli $\mathrm{O} 157: \mathrm{H} 7$ survival in ovine or bovine manure and manure slurry, Appl. Environ. Microbiol. 64 (1998) 3166-3174.

[93] Kudva I.T., Jelacic S., Tarr P.I., Youderian P., Hovde C.J., Biocontrol of Escherichia coli O157 with O157-specific bacteriophages, Appl. Environ. Microbiol. 65 (1999) 37673773.

[94] Kurokawa K., Tani K., Ogawa M., Nasu M., Abundance and distribution of bacteria carrying sltII gene in natural river water, Lett. Appl. Microbiol. 28 (1999) 405-410.

[95] Leclercq A., Mahillon J., Farmed rabbits and ducks as vectors for VTEC O157:H7, Vet. Rec. 152 (2003) 723-724.

[96] Lee S.H., Levy D.A., Craun G.F., Beach M.J., Calderon R.L., Surveillance for waterbornedisease outbreaks-United States, 1999-2000, Morb. Mortal. Wkly. Rep. Surveill. Summ. 51 (2002) 1-47.

[97] LeJeune J.T., Besser T.E., Hancock D.D., Cattle water troughs as reservoirs of Escherichia coli O157, Appl. Environ. Microbiol. 67 (2001) 3053-3057.

[98] LeJeune J.T., Besser T.E., Merrill N.L., Rice D.H., Hancock D.D., Livestock drinking water microbiology and the factors influencing the quality of drinking water offered to cattle, J. Dairy Sci. 84 (2001) 1856-1862.

[99] LeJeune J.T., Besser T.E., Rice D.H., Berg J.L., Stilborn R.P., Hancock D.D., Longitudinal study of fecal shedding of Escherichia coli O157:H7 in feedlot cattle: predominance and persistence of specific clonal types despite massive cattle population turnover, Appl. Environ. Microbiol. 70 (2004) 377-384. 
[100] Leomil L., Aidar-Ugrinovich L., Guth B.E., Irino K., Vettorato M.P., Onuma D.L., de Castro A.F., Frequency of Shiga toxin-producing Escherichia coli (STEC) isolates among diarrheic and non-diarrheic calves in Brazil, Vet. Microbiol. 97 (2003) 103-109.

[101] Lung A.J., Lin C.M., Kim J.M., Marshall M.R., Nordstedt R., Thompson N.P., Wei C.I., Destruction of Escherichia coli O157:H7 and Salmonella enteritidis in cow manure composting, J. Food Prot. 64 (2001) 1309_ 1314.

[102] Mainil J., Shiga/verocytotoxins and Shiga/ verotoxigenic Escherichia coli in animals, Vet. Res. 30 (1999) 235-257.

[103] Makino S., Kobori H., Asakura H., Watarai M., Shirahata T., Ikeda T., Takeshi K., Tsukamoto T., Detection and characterization of Shiga toxin-producin Escherichia coli from seagulls, Epidemiol. Infect. 125 (2000) 55-61.

[104] Marches O., Ledger T.N., Boury M., Ohara M., Tu X., Goffaux F., Mainil J., Rosenshine I., Sugai M., De Rycke J., Oswald E., Enteropathogenic and enterohaemorrhagic Escherichia coli deliver a novel effector called Cif, which blocks cell cycle G2/M transition, Mol. Microbiol. 50 (2003) 1553-1567.

[105] Maule A., Survival of verocytotoxigenic Escherichia coli $\mathrm{O} 157$ in soil, water and on surfaces, Symp. Ser. Soc. Appl. Microbiol. 88 (2000) 71S-78S.

[106] McCarthy T.A., Barrett N.L., Hadler J.L., Salsbury B., Howard R.T., Dingman D.W. Brinkman C.D., Bibb W.F., Cartter M.L., Hemolytic-Uremic Syndrome and Escherichia coli $\mathrm{O} 121$ at a Lake in Connecticut 1999, Pediatrics 108 (2001) E59.

[107] McDowell D.A., Sheridan J.J., Survival and growth of Vero cytotoxin-producing $E$. coli in the environment, in: Duffy G., Garvey P., McDowell D. (Eds.), Verocytotoxigenic Escherichia coli, Food \& Nutrition Press Inc., Trumbull, 2001, pp. 279-304.

[108] McGowan K.L., Wickersham E., Strockbine N.A., Escherichia coli O157:H7 from water, Lancet 1 (1989) 967-968.

[109] McNamara B.P., Donnenberg M.S., A novel proline-rich protein, EspF, is secreted from enteropathogenic Escherichia coli via the type III export pathway, FEMS Microbiol. Lett. 166 (1998) 71-78.

[110] Melton-Celsa A.R., O'Brien A., Structure, biology, and relative toxicity of Shiga toxin family members for cells and animals, in: Kaper J.B., O'Brien A.D. (Eds.), Escherichia coli $\mathrm{O} 157: \mathrm{H} 7$ and other Shiga toxinproducing E. coli strains, American Society for Microbiology, Washington, DC, 1998 , pp. 121-128.

[111] Meng J., Doyle M.P., Microbiology of Shiga-Toxin-Producing Escherichia coli in foods, in: Kaper J.B., O’Brien A.D. (Eds.), Escherichia coli $\mathrm{O} 157: \mathrm{H} 7$ and other ShigaToxin-Producing E. coli, American Society for Microbiology, Washington, DC, 1998, pp. 92-108.

[112] Mermin J.H., Griffin P.M., Public health in crisis: outbreaks of Escherichia coli $\mathrm{O} 157: \mathrm{H7}$ infections in Japan, Am. J. Epidemiol. 150 (1999) 797-803.

[113] Meyer-Broseta S., Bastian S.N., Arne P.D. Cerf O., Sanaa M., Review of epidemiological surveys on the prevalence of contamination of healthy cattle with Escherichia colt serogroup O157:H7, Int. J. Hyg. Environ. Health 203 (2001) 347-361.

[114] Midgley J., Desmarchelier P., Pre-slaughter handling of cattle and Shiga toxin-producing Escherichia coli (STEC), Lett. Appl. Microbiol. 32 (2001) 307-311.

[115] Morabito S., Karch H., Mariani-Kurkdjian P., Schmidt H., Minelli F., Bingen E., Caprioli A., Enteroaggregative, Shiga-Toxin-producing Escherichia coli $\mathrm{O} 111: \mathrm{H} 2$ associated with an outbreak of hemolytic-uremic syndrome, J. Clin. Microbiol. 36 (1998) 840-842.

[116] Morabito S., Dell'Omo G., Agrimi U., Schmidt H., Karch H., Cheasty T., Caprioli A., Detection and characterization of Shiga toxin-producing Escherichia coli in feral pigeons, Vet. Microbiol. 82 (2001) 275-283.

[117] Morabito S., Tozzoli R., Oswald E., Caprioli A., A mosaic pathogenicity island made up of the locus of enterocyte effacement and a pathogenicity island of Escherichia coli O157:H7 is frequently present in attaching and effacing $E$. coli, Infect. Immun. 71 (2003) 3343-3348

[118] Mundy R., Petrovska L., Smollett K., Simpson N., Wilson R.K., Yu J., Tu X., Rosenshine I., Clare S., Dougan G., Frankel G., Identification of a novel Citrobacter rodentium type III secreted protein, EspI, and roles of this and other secreted proteins in infection, Infect. Immun. 72 (2004) 2288-2302.

[119] Nakazawa M., Akiba M., Sameshima T., Swine as a potential reservoir of Shiga Toxin-Producing Escherichia coli $\mathrm{O} 157: \mathrm{H} 7$ in Japan, Emerg. Infect. Dis. 5 (1999) 833834

[120] Nataro J.P., Kaper J.B., Diarrheagenic Escherichia coli, Clin. Microbiol. Rev. 11 (1998) 142-201.

[121] Nicholls L., Grant T.H., Robins-Browne R.M., Identification of a novel genetic locus 
that is required for in vitro adhesion of a clinical isolate of enterohaemorrhagic Escherichia coli to epithelial cells, Mol. Microbiol. 35 (2000) 275-288.

[122] O'Brien S.J., Adak G.K., Gilham C., Contact with farming environment as a major risk factor for Shiga toxin (Vero cytotoxin)-producing Escherichia coli 0157 infection in humans, Emerg. Infect. Dis. 7 (2001) 10491051.

[123] Ochoa T.J., Cleary T.G., Epidemiology and spectrum of disease of Escherichia coli O157, Curr. Opin. Infect. Dis. 16 (2003) 259-263.

[124] Ogden I.D., Fenlon D.R., Vinten A.J.A., Lewis D., The fate of Escherichia coli O157 in soil and its potential to contaminate drinking water, Int. J. Food Microbiol. 66 (2001) 111-117.

[125] Ogden I.D., Hepburn N.F., MacRae M., Strachan N.J., Fenlon D.R., Rusbridge S.M., Pennington T.H., Long-term survival of Escherichia coli $\mathrm{O} 157$ on pasture following an outbreak associated with sheep at a scout camp, Lett. Appl. Microbiol. 34 (2002) 100 104.

[126] Ohnishi M., Kurokawa K., Hayashi T., Diversification of Escherichia coli genomes: are bacteriophages the major contributors? Trends Microbiol. 9 (2001) 481-485.

[127] Ohnishi M., Terajima J., Kurokawa K., Nakayama K., Murata T., Tamura K., Ogura Y., Watanabe H., Hayashi T., Genomic diversity of enterohemorrhagic Escherichia coli $\mathrm{O} 157$ revealed by whole genome PCR scanning, Proc. Natl. Acad. Sci. USA 99 (2002) 17043-17048.

[128] Olsen S.J., Miller G., Breuer T., Kennedy M., Higgins C., Walford J., McKee G., Fox K., Bibb W., Mead P., A waterborne outbreak of Escherichia coli O157:H7 infections and hemolytic uremic syndrome: implications for rural water systems, Water Sci. Technol. 47 (2003) 7-14.

[129] Oswald E., Schmidt H., Morabito S., Karch H., Marches O., Caprioli A., Typing of intimin genes in human and animal enterohemorrhagic and enteropathogenic Escherichia coli: characterization of a new intimin variant, Infect. Immun. 68 (2000) 64-71.

[130] Paiba G.A., Wilesmith J.W., Evans S.J., Pascoe S.J., Smith R.P., Kidd S.A., Ryan J.B., McLaren I.M., Chappell S.A., Willshaw G.A., Cheasty T., French N.P., Jones T.W., Buchanan H.F., Challoner D.J., Colloff A.D., Cranwell M.P., Daniel R.G., Davies I.H., Duff J.P., Hogg R.A., Kirby F.D., Millar M.F., Monies R.J., Nicholls M.J.,
Payne J.H., Prevalence of faecal excretion of verocytotoxigenic Escherichia coli $\mathrm{O} 157$ in cattle in England and Wales, Vet. Rec. 153 (2003) 347-353.

[131] Paton J.C., Paton A.W., Pathogenesis and diagnosis of Shiga toxin-producing Escherichia coli infections, Clin. Microbiol. Rev. 11 (1998) 450-479.

[132] Paton A.W., Srimanote P., Woodrow M.C., Paton J.C., Characterization of Saa, a novel autoagglutinating adhesin produced by locus of enterocyte effacement-negative Shigatoxigenic Escherichia coli strains that are virulent for humans, Infect. Immun. 69 (2001) 6999-7009.

[133] Payne C.J., Petrovic M., Roberts R.J., Paul A., Linnane E., Walker M., Kirby D., Burgess A., Smith R.M., Cheasty T., Willshaw G., Salmon R.L., Vero cytotoxin-producing Escherichia coli $\mathrm{O} 157$ gastroenteritis in farm visitors, North Wales, Emerg. Infect. Dis. 9 (2003) 526-530.

[134] Perna N.T., Plunkett G. 3rd, Burland V., Mau B., Glasner J.D., Rose D.J., Mayhew G.F., Evans P.S., Gregor J., Kirkpatrick H.A., Posfai G., Hackett J., Klink S., Boutin A., Shao Y., Miller L., Grotbeck E.J., Davis N.W., Lim A., Dimalanta E.T., Potamousis K.D., Apodaca J., Anantharaman T.S., Lin J., Yen G., Schwartz D.C., Welch R.A., Blattner F.R., Genome sequence of enterohaemorrhagic Escherichia coli O157:H7, Nature 409 (2001) 529-533.

[135] Potter A.A., Klashinsky S., Li Y., Frey E., Townsend H., Rogan D., Erickson G., Hinkley S., Klopfenstein T., Moxley R.A., Smith D.R., Finlay B.B., Decreased shedding of Escherichia coli O157:H7 by cattle following vaccination with type III secreted proteins, Vaccine 22 (2004) 362-369.

[136] Pradel N., Livrelli V., De Champs C., Palcoux J.B., Reynaud A., Scheutz F., Sirot J., Joly B., Forestier C., Prevalence and characterization of Shiga toxin-producing Escherichia coli isolated from cattle, food, and children during a one-year prospective study in France, J. Clin. Microbiol. 38 (2000) 1023-1031.

[137] Pritchard G.C., Willshaw G.A., Bailey J.R., Carson T., Cheasty T., Verocytotoxin-producing Escherichia coli $\mathrm{O} 157$ on a farm open to the public: outbreak investigation and longitudinal bacteriological study, Vet. Rec. 147 (2000) 259-264.

[138] Pritchard G.C., Williamson S., Carson T., Bailey J.R., Warner L., Willshaw G., Cheasty T., Wild rabbits: a novel vector for verocytotoxigenic Escherichia coli O157, Vet. Rec. 149 (2001) 567. 
[139] Rabatsky-Ehr T., Dingman D., Marcus R., Howard R., Kinney A., Mshar P., Deer meat as the source for a sporadic case of Escherichia coli $\mathrm{O} 157: \mathrm{H} 7$ infection, Connecticut, Emerg. Infect. Dis. 8 (2002) 525-527.

[140] Ramachandran V., Hornitzky M.A., Bettelheim K.A., Walker M.J., Djordjevic S.P., The common ovine Shiga toxin 2-containing Escherichia coli serotypes and human isolates of the same serotypes possess a Stx2d toxin type, J. Clin. Microbiol. 39 (2001) 1932-1937.

[141] Randall L.P., Wray C., McLaren I.M., Studies on the development and use of a monoclonal sandwich ELISA for the detection of verotoxic Escherichia coli in animal faeces, Vet. Rec. 140 (1997) 112-115.

[142] Reid S.D., Herbelin C.J., Bumbaugh A.C., Selander R.K., Whittam T.S., Parallel evolution of virulence in pathogenic Escherichia coli, Nature 406 (2000) 64-67.

[143] Renter D.G., Sargeant J.M., Hygnstorm S.E., Hoffman J.D., Gillespie J.R., Escherichia coli $\mathrm{O} 157: \mathrm{H} 7$ in free-ranging deer in Nebraska, J. Wildl. Dis. 37 (2001) 755-760.

[144] Rios M., Prado V., Trucksis M., Arellano C., Borie C., Alexandre M., Fica A., Levine M.M., Clonal diversity of chilean isolates of enterohemorrhagic Escherichia coli from patients with hemolytic-uremic syndrome, asymptomatic subjects, animal reservoirs, and food products, J. Clin. Microbiol. 37 (1999) 778-781.

[145] Rogerie F., Marecat A., Gambade S., Dupond F., Beaubois P., Lange M., Characterization of Shiga toxin producing $E$. coli and $\mathrm{O} 157$ serotype isolated in France from healthy domestic cattle, Int. J. Food Microbiol. 63 (2001) 217-223.

[146] Rubini S., Cardeti G., Amiti S., Manna G., Onorati R., Caprioli A., Morabito S., Verocytotoxin-producing Escherichia coli $\mathrm{O} 157$ in sheep milk, Vet. Rec. 144 (1999) 56.

[147] Scheutz F., Beutin L., Pierard D., Smith H.R., Nomenclature of Verocytotoxins, in: Duffy G., Garvey P., McDowell D. (Eds.), Verocytotoxigenic Escherichia coli, Food \& Nutrition Press Inc., Trumbull, 2001, pp. 447452

[148] Schmidt H., Shiga-toxin-converting bacteriophages, Res. Microbiol. 152 (2001) 687695.

[149] Schmidt H., Scheef J., Morabito S., Caprioli A., Wieler L.H., Karch H., A new Shiga toxin 2 variant (Stx2f) from Escherichia coli isolated from pigeons, Appl. Environ. Microbiol. 66 (2000) 1205-1208.
[150] Schmidt H., Bitzan M., Karch H., Pathogenic aspects of Shiga toxin-producing E. coli infections in humans, in: Duffy G., Garvey P., McDowell D. (Eds.), Verocytotoxigenic Escherichia coli, Food \& Nutrition Press Inc., Trumbull, 2001, pp. 241-262.

[151] Schurman R.D., Hariharan H., Heaney S.B., Rahn K., Prevalence and characteristics of shiga toxin-producing Escherichia coli in beef cattle slaugtered on Prince Edward Island, J. Food Prot. 63 (2000) 1583-1586.

[152] Shere J.A., Bartlett K.J., Kaspar C.W., Longitudinal study of Escherichia coli $\mathrm{O} 157: \mathrm{H} 7$ dissemination on four dairy farms in Wisconsin, Environ. Microbiol. 64 (1998) 1390 1399.

[153] Shere J.A., Kaspar C.W., Bartlett K.J., Linden S.E., Norell B., Francey S., Schaefer D.M., Shedding of Escherichia coli O157:H7 in dairy cattle housed in a confined environment following waterborne inoculation, Appl. Environ. Microbiol. 68 (2002) 1947-1954.

[154] Shinagawa K., Kanehira M., Omoe K., Matsuda I., Hu D., Widiasih Dan Sugii S., Frequency of Shiga toxin-producing Escherichia coli in cattle at a breeding farm and at a slaughterhouse in Japan, Vet. Microbiol. 76 (2000) 305-309.

[155] Silvestro L., Caputo M., Blancato S., Decastelli L., Fioravanti A., Tozzoli R., Morabito S., Caprioli A., Asymptomatic carriage of Verocytotoxin-producing Escherichia coli $\mathrm{O} 157$ in farm workers in Northern Italy, Epidemiol. Infect. 132 (2004) 915-919.

[156] Smith D., Blackford M., Younts S., Moxley R., Gray J., Hungerford L., Milton T., Klopfenstein T., Ecological relationships between the prevalence of cattle shedding Escherichia coli $\mathrm{O} 157: \mathrm{H} 7$ and characteristics of the cattle or conditions of the feedlot pen, J. Food Prot. 64 (2001) 1899-1903.

[157] Stevens M.P., Van Diemen P.M., Frankel G., Phillips A.D., Wallis T.S., Efa1 influences colonisation of the bovine intestine by Shigatoxin producing Escherichia coli serotypes O5 and O111, Infect. Immun. 70 (2002) 5158-5166.

[158] Strachan N.J., Fenlon D.R., Ogden I.D., Modelling the vector pathway and infection of humans in an environmental outbreak of Escherichia coli O157, FEMS Microbiol. Lett. 203 (2001) 69-73.

[159] Tatsuno I., Kimura H., Okutani A., Kanamaru K., Abe H., Nagai S., Makino K., Shinagawa H., Yoshida M., Sato K., Nakamoto J., Tobe T., Sasakawa C., Isolation and characterization of mini-Tn $5 \mathrm{Km} 2$ insertion mutants of 
enterohemorragic Escherichia coli O157:H7 deficient in adherence to Caco-2 cells, Infect. Immun. 68 (2000) 5943-5952.

[160] Tauschek M., Strugnell R.A., Robins-Browne R.M., Characterization and evidence of mobilization of the LEE pathogenicity island of rabbit-specific strains of enteropathogenic Escherichia coli, Mol. Microbiol. 44 (2002) 1533-1550.

[161] Tesh V.L., Virulence of enterohemorrhagic Escherichia coli: role of molecular crosstalk, Trends Microbiol. 6 (1998) 228-233.

[162] Thorpe C.M., Hurley B.P., Acheson D.W., Shiga toxin interactions with the intestinal epithelium, Methods Mol. Med. 73 (2003) 263-273.

[163] Thran B.H., Hussein H.S., Hall M.R., Khaiboullina S.F., Shiga toxin-producing Escherichia coli in beef heifers grazing an irrigated pasture, J. Food Prot. 64 (2001) 1613-1616.

[164] Thran B.H., Hussein H.S., Hall M.R., Khaiboullina S.F., Occurrence of verotoxinproducing Escherichia coli in dairy heifers grazing an irrigated pasture, Toxicology 159 (2001) 159-169.

[165] Tkalcic S., Zhao T., Harmon B.G., Doyle M.P., Brown C.A., Zhao P., Faecal shedding of enterohemorrhagic Escherichia coli in weaned calves following treatment with probiotic Escherichia coli, J. Food Prot. 66 (2003) 1184-1189.

[166] Tozzi A.E., Gorietti S., Caprioli A., Epidemiology of human infections by Escherichia coli $\mathrm{O} 157$ and other verocytotoxin-producing E. coli, in: Duffy G., Garvey P., McDowell D. (Eds.), Verocytotoxigenic Escherichia coli, Food \& Nutrition Press Inc., Trumbull, 2001, pp. 161-179.

[167] Tozzi A.E., Caprioli A., Minelli F., Gianviti A., De Petris L., Edefonti A., Montini G., Ferretti A., De Palo T., Gaido M., Rizzoni G., Hemolytic Uremic Syndrome Study Group. Shiga toxin-producing Escherichia coli infections associated with hemolytic uremic syndrome, Italy, 1988-2000, Emerg. Infect. Dis. 9 (2003) 106-108.

[168] Trevena W.B., Hooper R.S., Wray C., Willswaw G.A., Cheasty T., Domingue G., Vero cytotoxin-producing Escherichia coli O157 associated with companion animals, Vet. Rec. 138 (1996) 400.

[169] Tu X., Nisan I., Yona C., Hanski E., Rosenshine I., Esp H., a new cytoskeletonmodulating effector of enterohaemorrhagic and enteropathogenic Escherichia coli, Mol. Microbiol. 47 (2003) 595-606.
[170] Upton P., Coia J.E., Outbreak of Escherichia coli $\mathrm{O} 157$ infection associated with pasteurised milk supply, Lancet 344 (1994) 1015.

[171] Urdahl A.M., Beutin L., Skjerve E., Zimmermann S., Wasteson Y., Animal host associated differences in Shiga toxin-producing Escherichia coli isolated from sheep and cattle on the same farm, J. Appl. Microbiol. 95 (2003) 92-101.

[172] Van Donkersgoed J., Berg J., Potter A., Hancock D., Besser T., Rice D., LeJeune J., Klashinsky S., Environmental sources and transmission of Escherichia coli $\mathrm{O} 157$ in feedlot cattle, Can. Vet. J. 42 (2001) 714 720.

[173] Vernozy-Rozand C., Mazuy C., Ray-Gueniot S., Boutrand-Loei S., Meyrand A., Richard Y., Evaluation of the VIDAS methodology for detection of Escherichia coli O157 in food samples, J. Food Prot. 61 (1998) 917920.

[174] Vernozy-Rozand C., Montet M.P., Lequerrec F., Serillon E., Tilly B., Bavai C., Ray-Gueniot S., Bouvet J., Mazuy-Cruchaudet C., Richard Y., Prevalence of verotoxin-producing Escherichia coli (VTEC) in slurry, farmyard manure and sewage sludge in France, J. Appl. Microbiol. 93 (2002) 473-478.

[175] Wallace J.S., Cheasty T., Rowe B., Isolation of Vero cytotoxin-producing Escherichia coli $\mathrm{O} 157$ from wild birds, J. Appl. Microbiol. 82 (1997) 399-404.

[176] Wang G., Zhao T., Doyle M.P., Fate of enterohemorrhagic Escherichia coli $\mathrm{O} 157: \mathrm{H} 7$ in bovine feces, Appl. Environ. Microbiol. 62 (1996) 2567-2570

[177] Wasteson Y., Epidemiology of verocytotoxin-producing $E$. coli in non-ruminant animals, in: Duffy G., Garvey P., McDowell D. (Eds.), Verocytotoxigenic Escherichia coli, Food \& Nutrition Press Inc., Trumbull, 2001, pp. 149-160.

[178] Whittam T.S., Wolfe M.L., Wachsmuth I.K., Orskov F., Orskov I., Wilson R.A., Clonal relationships among Escherichia coli strains that cause hemorrhagic colitis and infantile diarrhea, Infect. Immun. 61 (1993) 16191629.

[179] Widiasih D.A., Ido N., Omoe K., Sugii S., Shinagawa K., Duration and magnitude of faecal shedding of Shiga toxin-producing Escherichia coli from naturally infected cattle, Epidemiol. Infect. 132 (2004) 67-75.

[180] Wieler L.H., Bauerfeind R., STEC as a veterinary problem. Diagnostics and prophylaxis in animals, Methods Mol. Med. 73 (2003) 75-89. 
[181] Wieler L.H., Bauerfeind R., Baljer G., Characterization of Shiga-like toxin producing Escherichia coli (VTEC) isolated from calves with and without diarrhoea, Zentralbl. Bakteriol. 276 (1992) 243-253.

[182] Wieler L.H., Vieler E., Erpenstein C., Schlapp T., Steinruck H., Bauerfeind R., Byomi A., Baljer G., Shiga toxin-producing Escherichia coli strains from bovines: association of adhesion with carriage of eae and other genes, J. Clin. Microbiol. 34 (1996) 2980-2984.

[183] Wieler L.H., McDaniel T.K., Whittam T.S., Kaper J.B., Insertion site of the locus of enterocyte effacement in enteropathogenic and enterohemorrhagic Escherichia coli differs in relation to the clonal phylogeny of the strains, FEMS Microbiol. Lett. 156 (1997) 49-53.

[184] Wieler L.H., Schwanitz A., Vieler E., Busse B., Steinruck H., Kaper J.B., Baljer G., Virulence properties of Shiga toxin-producing Escherichia coli (STEC) strains of serogroup O118, a major group of STEC pathogens in calves, J. Clin. Microbiol. 36 (1998) 1604-1607.

[185] Wilson J.B., Clarke R.C., Renwick S.A., Rahn K., Johnson R.P., Karmali M.A., Lior H., Alves D., Gyles C.L., Sandhu K.S., Mc Ewen S.A., Spika J.S., Vero cytotoxigenic
Escherichia coli infection in dairy farm families, J. Infect. Dis. 174 (1996) 1021-1027.

[186] Wray C., McLaren I.M., Carroll P.J., Escherichia coli isolated from farm animals in England and Wales between 1986 and 1991 , Vet. Rec. 133 (1993) 439-442.

[187] Wright D.J., Chapman P.A., Siddons C.A., Immunomagnetic separation as a sensitive method for isolating Escherichia coli $\mathrm{O} 157$ from food samples, Epidemiol. Infect. 113 (1994) 31-39.

[188] Zhao T., Doyle M.P., Shere J., Garber L., Prevalence of enterohemorrhagic Escherichia coli $\mathrm{O} 157: \mathrm{H} 7$ in a survey of dairy herds, Appl. Environ. Microbiol. 61 (1995) 12901293.

[189] Zhang W., Bielaszewska M., Kuczius T., Karch H., Identification, characterization, and distribution of a Shiga toxin 1 gene variant (stx(1c)) in Escherichia coli strains isolated from humans, J. Clin. Microbiol. 40 (2002) 1441-1446.

[190] Zhang W.L., Kohler B., Oswald E., Beutin L., Karch H., Morabito S., Caprioli A., Suerbaum S., Schmidt H., Genetic diversity of intimin genes of attaching and effacing Escherichia coli strains, J. Clin. Microbiol. 40 (2002) 4486-4492. 